\title{
Historical and Philosophical Prerequisites for the Analysis of Cognition Objectivity in the Social Sciences
}

\section{Prerrequisitos históricos y filosóficos para el análisis de la objetividad cognitiva en las ciencias sociales}

\section{Vyacheslav I. Korotkikh}

Doctor of Philosophy, Associate Professor, Professor of the Department of Philosophy and Social Sciences, Bunin Yelets State University, Yelets, Russia,

ORCID ID: https://orcid.org/0000-0002-9205-0157

*Correspondence

Email: professor-korotkikh@yandex.ru

\section{Cite as:}

Korotkikh, V.I. (2021). Historical and Philosophical Prerequisites for the Analysis of Cognition Objectivity in the Social Sciences. Propósitos y Representaciones, 9(SPE2), e1010. Doi: http://dx.doi.org/10.20511/pyr2021.v9nSPE2.1010 


\section{Summary}

The article deals with the analysis of the sociality construction in Hegel's The Phenomenology of Spirit, which is the prerequisite for the development of current social and humanitarian knowledge. The author introduces the idea that a decisive factor for the formation of the Method of the Humanities and Social Sciences is Hegel's reconsideration of the idea of the immediacy of social relations as a subject for philosophical consideration. Sociality construction, compared to the uncritical perception of Society as an object that is available for observation as a natural object, provides a consistent and methodically substantiated disclosure of the essential characteristics of social life. In The Phenomenology of Spirit, Hegel describes Sociality forms as necessary steps for the movement of the spirit toward self-cognition. Reasonable development of social relations is based on their sphere of selfconsciousness attributes, which unlike the previous formations of the consciousness (die Gestalt and die Gestaltung that in various English translations are form, mode, shape, and figure) reveal that truth is not in the object but in unity with the self. Thus, the most significant discovery of the philosopher is that consciousness "pushes its boundaries" and overcomes imaginary singularity. In addition, "the doubling of consciousness" contributes to the formation of sociality as a sphere in which the spirit is capable of revealing substance concretion. The concept of sociality, which is first described in the chapter on consciousness, is revealed in the subsequent sections. As a result, social relations become the main concept of Hegel's work. The development of this concept is not only philosophically and systematically significant. As it is presented in this article, social relations substantiate the possibility of overcoming subjective, for example, "evaluative" approaches to the consideration of social life based on the idea of the immediacy of social relations. Moreover, this concept reveals the essential nature of sociality formation and its existence in various forms of spirit. The results of this research can be regarded as verification of the provision that the method of sociality construction presented in The Phenomenology of Spirit provides cognition of social life via rational means and the argumentativeness of social and humanitarian knowledge. Thus, the foundations for the scientific study of human and society can be developed.

Keywords: social sciences, humanities, the objectivity of cognition, method, Hegel's philosophy, The Phenomenology of Spirit

\section{Resumen}

El artículo trata del análisis de la construcción de la socialidad en La fenomenología del espíritu de Hegel, que es el requisito previo para el desarrollo del conocimiento social y humanitario actual. El autor introduce la idea de que un factor decisivo para la formación del Método de las Humanidades y las Ciencias Sociales es la reconsideración de Hegel de la idea de la inmediatez de las relaciones sociales como tema de consideración filosófica. La construcción de la socialidad, en comparación con la percepción acrítica de la sociedad como un objeto que está disponible para la observación como un objeto natural, proporciona una revelación consistente y metódicamente fundamentada de las características esenciales de la vida social. En La fenomenología del espíritu, Hegel describe las formas de socialidad como pasos necesarios para el movimiento del espíritu hacia el autoconocimiento. El desarrollo razonable de las relaciones sociales se basa en su esfera de atributos de autoconciencia, que a diferencia de las formaciones previas de la conciencia (die Gestalt y die Gestaltung que en varias traducciones inglesas son forma, modo, forma y figura) 
revelan que la verdad no es en el objeto pero en unidad con el yo. Así, el descubrimiento más significativo del filósofo es que la conciencia "empuja sus límites" y supera la singularidad imaginaria. Además, "la duplicación de la conciencia" contribuye a la formación de la socialidad como ámbito en el que el espíritu es capaz de revelar la concreción de la sustancia. El concepto de socialidad, que se describe por primera vez en el capítulo sobre la conciencia, se revela en las secciones siguientes. Como resultado, las relaciones sociales se convierten en el concepto principal de la obra de Hegel. El desarrollo de este concepto no es solo filosófica y sistemáticamente significativo. Como se presenta en este artículo, las relaciones sociales sustentan la posibilidad de superar enfoques subjetivos, por ejemplo, "evaluativos" de la consideración de la vida social a partir de la idea de la inmediatez de las relaciones sociales. Además, este concepto revela la naturaleza esencial de la formación de la socialidad y su existencia en diversas formas de espíritu. Los resultados de esta investigación pueden considerarse como una verificación de la provisión de que el método de construcción de la socialidad presentado en La fenomenología del espíritu proporciona el conocimiento de la vida social a través de medios racionales y la argumentación del conocimiento social y humanitario. Así, se pueden desarrollar las bases para el estudio científico del ser humano y la sociedad.

Palabras clave: ciencias sociales, humanidades, objetividad de la cognición, método, filosofía de Hegel, Fenomenología del espíritu.

\section{Introduction}

Thinkers turned to the study of "the book of nature" at the beginning of the 17th century and concluded that it had been written in "the language of mathematics." For the past four centuries since then, mathematical natural science has remained a scientific model for those areas of human knowledge in which "measure, number, and weight" are not capable of guaranteeing the achievement of the adequacy and accuracy of knowledge. Moreover, attempts to extend the principles, which have proven their fruitfulness in the study of nature, to humans, society, and culture have more than once led to the loss of the very "objectivity" of social and humanitarian knowledge. Therefore, a human is reduced to "human nature," a certain stable "subjectless being." However, it is possible to describe a human as other natural objects. Some insightful remarks on human and social individuality as objects of possible scientific cognition, for which the "geometric mind" is insufficient (B. Pascal, J. Vico), could not fundamentally influence the perception of the humanities and social sciences as a set of random ideas, whose characteristics rather depend on the preferences or the arbitrary imagination than on real research.

By the end of the 18th century, when the worldview of romanticism was formed based on the "critique of reason," ideas arose that did not fit the framework of the natural science ideal of classical rationalism and the ideology of enlightenment, namely, the ideas of historicism and hermeneutics. However, it was difficult to incorporate these new approaches into science; they were easily adjusted to the artistic or religious consciousness, which did not correspond to the philosophical and scientific ideas on the unity of reason in all spheres of knowledge and the invariability of its principles. Later, positivism spread as a "scientific philosophy," although the objective to develop the methods for studying humans and society is still introduced in the context of the 
universality of the naturalistic model of cognition. The idea of sociology expressed by Comte coincides completely with the idea of "normal" science, which must correspond to the principles that have been justified in natural science. Two centuries earlier, Pascal had declared that the study of humans and society could not be carried out via the same methods as the study of nature; moreover, the specifics of the subject itself should determine research methodology. However, this thought could not be accepted in the era of positivism. Only by the end of the 19th century, Dilthey and other followers of classical philosophy as a fruitful context for the revival of philosophical thought and the development of the humanities and social sciences began to form prerequisites for enriching the methodology of society and culture studying with the approaches that previously had been out of the philosophical research interest.

And it is not a coincidence that today, as in the days of Dilthey, and regardless of the researchers' attitude to one or another ideological trend, the necessity to rethink the methodology of the humanities and social sciences prompts us to appeal to the experience of historicism and hermeneutics development, which can be called the era of "romanticism" in the enlarged sense of the word. Foucault declared that it was at the end of the 18th to the beginning of the 19th century when a human became a new subject of science and, accordingly, "the humanities" in the modern sense emerged. Moreover, in this context, it is necessary to pay attention to Foucault's concept as we can observe the fulfillment of his famous prediction through the form of "transhumanism", "post-humanism", etc., i.e., a person like "an invention of recent date" "would be erased, like a face drawn in sand at the edge of the sea" [7, p. 386]. Therefore, the crisis of "classical humanism" led to the necessity to preserve humanitarian knowledge as a common cultural heritage of humankind. Regardless of how long a person is destined to remain the "main character" of the humanities and social sciences, it can be stated that even currently the researchers, who are involved in this area are tending to reflect human existence and maintain hope for an objective analysis of social problems.

Without being bound by the positivist paradigm of "scientific sociology", the researchers constantly return to the historical and methodological foundations of social and humanitarian cognition, which first began to be realized in the era of Herder, Schleiermacher, and Hegel. The main objective of the present work is to evaluate the significance of the most important historical and philosophical prerequisite for modern social and humanitarian knowledge, namely, Hegel's "construction" of social reality and the corresponding subject of activity, and cognition, which are reflected in The Phenomenology of Spirit. In our opinion, Hegel's understanding of the sociality essence marked the most important stage in the search for new methodological foundations for the humanities and social sciences. Unfortunately, the scope of the article rather allows us to highlight the very principle of sociality construction than to analyze its detailed implementation in Hegel's text. Therefore, only one fragment of The Phenomenology, which is basic for understanding the essence of social and humanitarian knowledge, is analyzed. However, the understanding of even this fragment of Hegel's work, which was created precisely in that crucial era, when discoverers and enthusiasts were just developing the tools for the realization of a "new science" project, which was formulated a century earlier by Vico, can contribute to the understanding of the reconstruction of the historical and philosophical prerequisites for the formation of the humanities and social sciences. The achievement of this goal in terms of random observations and information that is something like coastal sand for a science model, based on "measure, number, and weight", provides the opportunity to see a "face" for 
the first time, i.e., a person in a social and cultural environment, who has been the subject of social and humanitarian knowledge for two centuries.

\section{Methodology}

It is necessary to highlight two terms related to the chosen methods for the analysis of The Phenomenology of Spirit as a prerequisite for the development of modern social and humanitarian knowledge. The term "construction" in the context of Hegel's philosophy may not seem entirely relevant, since it was widely used by the researcher's opponents. Subsequently, the philosopher formed a negative attitude toward this word, as it was observed with the term "transcendental". However, it is "construction" that properly describes the process that is revealed in The Phenomenology, i.e., social relations and forms of culture emerge, being composed of some simpler elements of "the experience of consciousness" that are not conditioned by sociality. These elements, like threads interlaced with one another, form the "fabric" of social life, history, and culture. We intend to substantiate the provisions according to which the construction of sociality was considered by the philosopher as an essential element for the justification of social and humanitarian knowledge. In the context of Hegel's works, it means the inclusion of this type of knowledge in The System of Science (Jena project on the system of philosophy) or, later, in the Encyclopedia of Philosophical Sciences. The interpretation of the "structuredness" of social life, understanding that its images emerge in the "experience of consciousness" as a result of synthesis, predetermines its cognition through rational means and the "evidentiality" of the knowledge obtained.

In The Phenomenology, unlike his previous works, Hegel does not regard social life, human, and culture as some "ingenuousness"; he tries to reveal the way these complex formations emerge in a holistic "experience of consciousness," which by design cover all types of thingness available for cognition. In addition, the correlation of the problem of sociality construction, which was deeply studied in The Phenomenology, with the materials characterizing the spiritual development of "young Hegel", rather explains his refusal to accept the rights of non-rational methods of cognition in philosophy than demonstrates the philosopher's overcoming of the idea of social life immediacy as an object of thought, its unconditional "availability" for thinking. It found its completion in the proclamation of the concept as the only adequate form of comprehension of the Absolute. We posit that it was exactly the involvement in social problems, which illuminated the correlation between the idea of objectivity construction within the "experience of consciousness" and the possibility of its conceptual comprehension, that inexorably catalyzed Hegel's shift from a "romantic" worldview of the Frankfurt period. That is, the genesis of the issue ensconcing Hegelian philosophy, which is revered in the historical repertoire of European culture.

We deem it necessary to explicate the term "sociality". Notably, there is no expression in The Phenomenology of Spirit, which could be translated as "sociality". However, some "layers" of narration are perspicuously distinguished in Hegel's text. They are characterized not only by the correlation with social being, but also by the inclusion of the processes of consciousness evolution in the system of social relations. The general features of these distinct levels of objectivity will be identified with the term "sociality". ${ }^{1}$ In socio-philosophical, sociological, and psychological literature, the

\footnotetext{
${ }^{1} \mathrm{We}$ are of the view that in the process of the content analysis of the works under study, the researcher is free to use the concepts that were not presented in the texts themselves since the development of "metalanguage" that best meets the assigned tasks is a key requirement for scientific research. In addition,
} 
concept of sociality imbues a variety of semantic loads: from the generalized denotation of a personality's socio-psychological attributes and the edifice of socialization processes, etc. to the totality of social relations within an era, region, or a set of typological and other characteristics of society. In this article, the usage of this term pertains to "object" interpretation, regardless of the rudimentary principles for the sociality determination. According to our interpretation of "The Phenomenology", the concept of sociality combines the "types" of objectivity that were identified by the philosopher $[1 ; 2 ; 32 ; 33]^{2}$ Hegel frequently appeals to the concept of objectivity, considered in the social life context, to elucidate "the experience of consciousness". Accordingly, the concept, which we identify designate as "sociality", is developed.

Notwithstanding his prominent "Science of Logic" or "Philosophy of Nature", Hegel is mostly regarded as a social thinker. We concede that this widespread view does have merit. This statement is demonstrated by the thinker's "youthful manuscripts", i.e., all his early works up to the beginning of the "Jena period" $[12 ; 13]$. Nowadays, the author of such orientation would rather be called a historian, sociologist, or culturologist than a philosopher. Only in Jena, both under the confluence of the traditions of university teaching and the desire to develop a complete system, is there a "universalization" of Hegel's interests, who was mastering new areas of philosophical knowledge. However, it does not lead to the refusal to consider social problems.

The concern with social issues does not necessarily lead to a systematic reflection on the objectivity of the results obtained. Such a reflection was not observed during Berne and Frankfurt periods of the philosopher's work. It is possible that the fact that the "youthful manuscripts" had been created before the development of Hegel's idea of a consistent substantiation of socio-historical knowledge predetermined their subsequent fate. Obviously, the philosopher set a high value on them, as he kept them despite frequent travels, which were sometimes rather dramatic. However, Hegel made no attempt to publish or even revise these materials to be applicable for publication. ${ }^{3}$ Apparently, Hegel understood the difference between the fragments that had been written before the systematic substantiation of the objectivity of social and humanitarian knowledge and his later works, which did not allow uniting these talented sketches with a "system" that originated in Jena. However, they will have a significant effect when they become available to the reader. In the present article, we are trying to show that the key point for the development of a completely new way of understanding a human and society is a kind of "sociality construction", which has become one of the most important tasks of The Phenomenology of Spirit. It allows us to review the issue of the possibility of their scientific and philosophical substantiation in terms of a current distrust of the humanities and social sciences.

we should consider the specific essence of "The Phenomenology" language, which was carefully developed by the author to describe the universal "experience of consciousness", excluding from it, to the greatest extent possible, the expressions that are not necessary for the attainment of the goal.

2 Therefore, if we try to imagine how this term could be incorporated into Hegel's text, it would rather correspond to "das Gesellschaftswesen" than to "die Sozialität", which has an emphasised "subjective" meaning.

${ }^{3}$ Discovered after the death of the philosopher and partially became known thanks to Rosenkrantz [31], although they were included in the list for academic reading only at the beginning of the last century, thanks to Dilthey [4] and Nol [28]. The Russian reader is also familiar with the main materials of this period thanks to the translations, which were made on the basis of Nol's work results [11; 15]. One of the editions contains a comic typo [15, p. 645, 647]. In terms of the historical-critical publication of Hegel's works, it was established that Nol erroneously tried to observe the image of a single growing creation among the fragments known to him. Actually, there was a return to the same material, and attempts of its new editions [30]. 
The peculiarities of The Phenomenology structure, which determine the necessity to return to the issue of sociality construction, as well as to all other basic plots, will not be discussed in the article deliberately, since we considered this question sufficiently in previous publications $[19 ; 21]$. It is worth highlighting that the "linear" dimension of the movement of the "experience of consciousness" consists of a sequence of structurally homogeneous cycles, which were separated by the "breaks" and "backward motions" of the narration. However, these features of the text are not fundamental for the understanding of the possibility of social life cognition using "science" ("systematic philosophy"), the disclosure of which is assumed by the article. However, it is necessary to emphasize one of the features of the "phenomenological method", according to which the content of the "experience of consciousness" initially appears for the author and the reader ("for us", for "our consciousness"), and later appears for the "consciousness itself", the movement of which is the immediate subject of consideration. This is precisely the characteristic of the method of The Phenomenology, which predetermines its linear-cyclic structure.

Thus, the principle of sociality construction as a type of objectivity should be in the foreground in the process of a work consideration, which contributes to the possibility to develop the basis for objective, evidence-based knowledge about a personality, society, and culture. Therefore, we rely on traditional methods of historical and philosophical reconstruction, which reveal the origin and essence of social reality. In addition, we use the elements of phenomenological, comparative, and hermeneutic methods, since the described content must be correlated with the subject of the "experience of consciousness", the content of other Hegel's works, his predecessors, and contemporaries. Moreover, it is necessary to reveal the correlation between certain Hegel's ideas and structures and the circumstances of the historical era, culture peculiarities of that time, and, finally, with the uniqueness of the spiritual image of the author himself, which makes to appeal to Hegel's reflections on human and society more than two centuries afterwards.

\section{Results}

The construction of sociality in the context of the movement of the "experience of consciousness", as it was revealed in the essence of the "youthful manuscripts", replaces Hegel's understanding of social life as a kind of "immediacy", which is homogeneous with the simplest forms of perception of the objective world. At this stage of the content of The Phenomenology of Spirit, the "structure" of social life, order, and lawfulness of its main characteristics are revealed. Therefore, it becomes possible to substantiate the objectivity of the knowledge that reflects them. However, the achievement of this result does not take the researcher off another important problem of the humanities and social sciences, namely, the problem of the interrelation between the stability, steadiness of social characteristics, and their variability. We admit that the understanding of sociality as immediacy inevitably leads to its "fluidity" recognition, as it is associated with Heraclitus and Cratylus in the history of philosophy. Although, the "synthetic" essence of social reality contributes to the possibility of its "restructuring". Each particular case (era and culture), as well as sociality specifics are determined by a unique constellation of social life determinations that have been formed in the course of the historical development. Thus, is there a sense to distinguish a specific "invariant", if it is proceeded from the process of "phenomenological construction" of sociality, could be perceived as a "norm", or at least a reference point? Obviously, only in relation to such a reference point, real society can be understood as a pattern that is original in each 
specific case, reproducing, however, the necessary structural elements of the same phenomenological construct. Can we believe that the model of sociality, which is developed in the "experience of consciousness", should be kept in any specific historical environment, and the laws of its evolution, discovered in The Phenomenology, should be reproduced in a more or less "pure form" in the real historical experience of various nations and eras?

Ultimately, in The Phenomenology of Spirit as well as in later works, Hegel answers these questions affirmatively. The researcher's conviction that in sociohistorical existence universal laws prevail over "historical accidents" is based on the idea that the emergence of self-consciousness in the context of phenomenological experience can be considered as a starting point for sociality construction. The importance of this provision for the understanding of sociality essence is due to the fact that self-consciousness distinguishes the truth no longer in the object, like the previous formations, but in itself, in the unity with self. However, the relations, conditioned by the structural relations revealed in the "experience of consciousness," are prevailing over the "external" influence of objectivity. This contributes to the emergence of the thesis about the consciousness of freedom as a criterion of social progress. Therefore, nothing can arise in a socio-historical being that does not exist in the "transcendental prehistory", in sociality as a kind of transcendental-phenomenological "frame" of any manifestations of social life. It is worth highlighting the main points of the construction of the initial form of sociality, which will be carried out in the sphere of selfconsciousness. Since, if there is no self-consciousness, there are also no social characteristics.

The concept of the sociality essence originates in the introductory part of Chapter 4. Hegel offers a "sketch" of more specific description of the experience, as he usually does in introductory parts of other sections. To understand such parts of the work, which are presented, however, not only in the introductions, we must draw on a particular point of the method The Phenomenology, namely, that the content of these "sketches-anticipations" appears "for right now" (in "time" of the "experience of consciousness") not to "the consciousness itself", but only to "us", to the "observing consciousness". "Our consciousness", which occupies a more "convenient" position, allowing us to perceive the movement of experience as a whole, already sees the content, which the consciousness, involved in the experience, will see "later"; and then the same content (but with many details, which is due to the "difficulty" of its experience) will be reproduced from our point of view. The movement of the experience in this respect can be explained by comparing it with the course of a battle: the commander who is on a hill already sees where the decisive battles are unfolding. The "logic" of the battle and its outcome are already clear to him. Although, the soldiers will understand it only at the end of the battle, and only through terrible suffering.

Concerning the provision of self-consciousness as the starting point of sociality construction, it is worth emphasizing the fact that its objectivity is twofold, i.e., consciousness is regarded as its own object, and the objectivity of the previous stages of movement, which is preserved, except for the recognition of the being independence of the objects of sensible reliability, perception, and understanding. Since, selfconsciousness considers the truth only in unity with itself, not with the object, this "external" component of self-consciousness objectivity must be removed; selfconsciousness regards it as something negative. Hegel determines the removal of objectivity in the process of sociality construction is as a "desire" (die Begierde) [14, p.

\footnotetext{
${ }^{4}$ We try to keep Hegel's insistent use of the constructions describing the "experience of consciousness": the subject appears in the experience "to it", but "to us."
} 
153]. "Desire" is Hegel's first concrete element of sociality. Therefore, we concern about the status of this and the following "concepts". Can they be regarded as concepts? - Formally, they cannot. Moreover, this is not a category, because we are analyzing the "experience of consciousness", where the crystallization of the concept meanings and movement toward the logical environment originates (at the early stage of movement). It is worth emphasizing, that in The Phenomenology, all semantic formations have a sensory-intuitive component that influences the figurative character of speech in Hegel's work. In terms of our study, we can afford not to descend in particulars, although determine the indicated semantic formations of experience as elements of sociality construction.

Further, the subject of self-consciousness, which in its perception has a "negative character", "for us", that is, "in itself" returned into itself just as consciousness... By way of this reflective turn into itself, the object has become life... The object of immediate desire is something living" [ibid, p. 153]. Here again we have the "observing consciousness" of the author and the reader, the "commander" sees what the "consciousness itself" does not yet see, i.e., the self-consciousness immersed in experience remains "in itself". Thus, the objective correlate of self-consciousness is life, i.e., something living. Referring to this object with the character of negativity, selfconsciousness acts as lust. ${ }^{5}$

The subsequent disclosure of the concept of life puts the object of selfconsciousness lust "on the same level" with it, since the image of life, as well as the image of self-consciousness, reveal the "infinity" as a fundamental structure of speculative objectivity, which the consciousness is led to by the experience movement at each of the stages. Life is regarded as a process, in terms of which the fluidity, as its simple essence, and the differences observed in it (species and individuals) are simultaneously opposed to each other and merge into a unity ${ }^{6}$. From the point of view of self-consciousness, the meaning of this experience is in the establishment of the insignificance of its object as a lust, and thereby becomes convinced of its reliability: "In this satisfaction it learns from experience about the self-sufficiency of its object. Desire and the certainty of itself achieved in its satisfaction are conditioned by the object, for the certainty exists by way of the act of sublating of this other. For this act of sublating even to be, there must be this other. Self-consciousness is thus unable by way of its negative relation to the object to sublate it, and for that reason it once again, to an even greater degree, re-engenders the object as well as the desire" [ibid, p. 158-159]. Then Hegel claims that "there is in fact another than self-consciousness, the essence of desire" [ibid, p. 159]. Actually, self-consciousness goes way beyond lust; the latter is only the first point of its experience movement.

We provided the citation, since the correlation that is opened up to the reader between what "our consciousness", which "anticipates" the experience, sees and how this picture is transformed in terms of the activity of "consciousness itself" confirms the validity of the main ideas and the concept of the present article. We consider the abovementioned problematic understanding of the role of general schemes, models, universal structures of social being, and their specific manifestations in the context of the sociohistorical life of humankind. The Phenomenology reveals that the conceptual categorical

\footnotetext{
${ }^{5}$ Hegel refers to life images in The Phenomenology for several times, seeking to distinguish them terminologically. Thus, in the first section of Chapter 5 the thinker draws on the objectivity not with "practical", but with "cognitive" interest. Here he determines it as "organic".

${ }^{6}$ As we can see, the general hostility of individuals is reflected at the level of life as an object of selfconsciousness. It influences the emergence of society, i.e., "bellum omnium contra omnes" by Hobbes or "uncommunicative sociability" by Kant.
} 
understanding of sociality as an "antagonist" of the pseudo-reliable (exceedingly respected by some historians and sociologists) comprehension of socio-historical processes exclusively "on the basis of facts" is not the only way for the understanding of social being. Hegel provides the possibility to move along the creation of a "phenomenology of socio-historical being" through sociality construction as the most important "layer" of the "experience of consciousness". A distinctive feature of the "phenomenology of socio-historical being", as compared to the philosophy of spirit, philosophy of law, and philosophy of history, is not an appeal to rational (logical) structures in the usual sense, but to the structures of the "experience of consciousness", which are by no means limited by reason norms. Self-consciousness, mind, spirit, and other images of consciousness, which realize the "infinity" as a speculative completion of the experience at each stage, do not deplete the life of the consciousness, in which all elements of experience are stored and, accordingly, manifest in socio-historical being, i.e., the lust as the basis of all subsequent structures of sociality.

Thus, self-consciousness rather generates permanently the object of the lust than the lust itself. Therefore, it is an independent and necessary element of its experience. The independence ("subjectivity") of an object means that it is not simply removed by self-consciousness, although it is a negation itself. Therefore, has the same dialecticalspeculative essence as consciousness. From this follows the famous Hegel's thesis about the "doubling of self-consciousness". If self-consciousness as lust initially regards the removed object as a "thing", then its experience reveals that this object is selfconsciousness: "Self-consciousness attains its satisfaction only in another selfconsciousness" [ibid]. The "doubling of self-consciousness" is the true origin of sociality, because, in lust, self-consciousness has not yet recognized itself in its subject. Thus, we can say that the "circle of self-consciousness" has been closed.

This closing "circle of self-consciousness" is a spirit; the truth (recalling the main characteristic of the method of "experience of consciousness"), which is revealed so far only for us, "our consciousness", while the consciousness we observe, "woven" into the difficult, dramatic movement of the experience, should survive two more "battles" in Chapter 4. Its detailed description will constitute its main content. Hegel declares: "The concept of spirit is thereby on hand for us. What will later come to be for consciousness will be the experience of what spirit is, that is, this absolute substance which constitutes the unity of its oppositions in their complete freedom and selfsufficiency, namely, in the oppositions of the various self-consciousnesses existing for themselves: The $I$ that is we and the we that is I" [ibid, p. 160].

Thus, sociality as a specific characteristic of the subject of consideration is formed in the "experience of consciousness", although the substance that constitutes the basis of individual self-consciousness appears as their "negative essence". In this respect, the life of self-consciousness can be illustrated by the example of its object life: in the genus, which is a fluid negative essence of life, individual living beings disappear, and sociality as the substance of the life of self-consciousness also appears only in the struggle and mutual removal of the individuals. Lust, the negation of another independent self-consciousness, gives impetus to the process of the sociality construction, and the spirit in which the "other" self-consciousness is accepted as "one's own" identifies the culmination of this process. At the same time, only a negative attitude toward the independence of another self-consciousness ("lust") is replaced by its "incorporation" into the developing structure of sociality, its "removal" in a more common "dialectical" meaning. As a result, sociality is formed as a "reflected unity" of the interacting independent self-consciousnesses. 
At the end of the analysis of the introductory part of Chapter 4, it is worth highlighting the last sentence, in which Hegel, very figuratively representing the moment in the development of experience, answers the question about the meaning of the construction of sociality sphere in the context of the "experience of consciousness" as a whole. As it was already mentioned, the issue of socio-historical being was described sufficiently. What is the reason for this situation? This formula allows us to state that Hegel sees the immanent element of the spirit in sociality, in which it reveals its content and reaches the degree of speculative concreteness, which, under the name of the "Absolute knowledge", will crown the entire path of The Phenomenology of Spirit: "As the concept of spirit, consciousness first reaches its turning point in selfconsciousness, where it leaves behind the colorful semblance of the sensuous world and the empty night of the supersensible other-worldly beyond and steps into the spiritual daylight of the present" [ibid, p. 160-161].

The immanent logic of research prompts, at the point reached, to move on to the analysis of the two mentioned experiments of Chapter 4 in order to reveal the correlation of the described basic structures of sociality with the images, which they will appear more concretely to the consciousness involved by the experience. However, it is impossible to realize this intention within the framework of a separate article. Therefore, outlining the contours of new studies, designed to develop its concept, we can single out only the main sections of The Phenomenology, in which the deepening of the considered process of sociality construction will be carried out. In addition to the experiments presented in 4.A and 4.B devoted to the independence and the freedom of selfconsciousness (their content only concretizes the outline of the introductory part of the chapter, but does not go beyond it), we consider sections 5.B and 5.C, as well as Chapters 6, 7, 8. Moreover, in the first case, it is still possible to establish a correspondence based on the differences, which will be presented as the differences of the "objective" and "absolute" spirit within the framework of the "encyclopedic system". Although, in the second case it would be more difficult to establish it. Actually, this corresponds to the internal logic of the disclosure of sociality in The Phenomenology, since Hegel strove to see "ideas" behind the "institutions," the content obtained by the consciousness in the process of the experience. In The Philosophy of Spirit or The Philosophy of Law, the subjective, objective, and absolute spirit differ not only in their "certainty", and in ideological content, but also in the essence of the "bearer", i.e., in the corresponding parts of the system we concern the individual, social institutions or social consciousness. In the third block of "social chapters", such a distinction is almost impossible to trace. The specified features of the presentation reflect the main intention of The Phenomenology, i.e., the removal of the object of the consciousness in the experience that is only apparently alien to the consciousness, supposedly independent being, and the establishment of the unity with it. The consciousness that goes through this entire difficult path, realizes itself as a spirit.

\section{Discussion}

Regarding the internal structure of sociality as a type of relationship, which is fundamentally more complex and "concrete" than the objectivity of the previously passed stages, Hegel allows the reader of The Phenomenology to come closer to the understanding of the importance of sociality construction principle for substantiating the humanities and social sciences. Indeed, rejecting the idea of "immediacy" of perception and description of social being, presenting it as the result of a complex process of "semantic synthesis", the thinker provides the possibility of rejecting the opinion about social and humanitarian knowledge as only a set of random, "evaluative" judgments 
conditioned by the authors' interests and preferences. Sociality as special objectivity of the consciousness is inaccessible for direct perception; it is revealed only as a result of complex dialectical experience. Therefore, the awareness of "synthetic" essence of the objectivity of the humanities and social sciences allows and even requires an objective socio-philosophical and scientific analysis of the content of the relations that form the basis of social life, resulting from the initial phenomenological construct of sociality.

In order to assess the significance of the results obtained, we should take into account the complex reading history of the "social chapters" of The Phenomenology of Spirit, as the abundance and inconsistency of the approaches and interpretations of the socio-historical context of the work did not contribute to the identification of its significance for the substantiation of social and humanitarian cognition. Marx was one of the first to appreciate the analysis of labor, wealth, state power, and other elements of social life presented in The Phenomenology [25, p. 133-158]. Although, he emphasized that Hegel considers these phenomena only "in their form as thoughts" [ibid, p. 138], as a result of the alienation of "abstract philosophical thinking" [ibid]. The thinker believed that it contributes to later Hegel's "uncritical positivism" [ibid, p. 139] concerning contemporary society, which prevented the understanding of the necessity for real "sublating" ("alienation", "das Aufheben"), which would go beyond the limits of the philosophical "pure thinking" [ibid, p. 138]. ${ }^{7}$

Unfortunately, later, in the era of the dominance of the ideology of positivism, Marx's deep judgments about Hegel's philosophy could not be developed, and after Haym's work, The Phenomenology was regarded as a result of a strange mixture of history and psychology [10, P. 240- 244]. Since, only in history and psychology a researcher operates with "facts", which were recognized by the era of open oppression of philosophy for the sake of "science". Only in the last century, when the initiative to study "Phenomenology" passed to the representatives of French neo-Hegelianism, it was possible to return to the analysis of the socio-philosophical aspects of Hegel's work. However, within the framework of this movement, strictly scientific approaches to the consideration of sociality were practically not presented. Hippolyte begins to develop a critical view toward the "existentialist spirit" of French neo-Hegelianism [16]; this tendency was developed in Hegel studies in the following decades $[17 ; 20 ; 23$; $26 ; 27 ; 35]$. Recently, it has also been reflected in the search for a "non-metaphysical" image of Hegel's philosophy [9; 18; 24]. In this context, it is worth emphasizing the publications on the structure of Hegel's work, the form of the narrative, the language, and the specifics of the plot construction, rejecting the suspicions of the accidental design and imperfection of its implementation $[3 ; 5 ; 6 ; 34 ; 36 ; 37]$. Since, only in this case, it is possible to use Hegel's experience of sociality constructing to substantiate social and humanitarian knowledge. Thus, the identification of certain patterns during the "experience of consciousness" is possible due to the presence of the "observer" in its structure, namely, "our consciousness" [8;22;29]. Sociality construction acts as a natural development of experience, namely, that stage at which the spirit moving toward self-cognition takes a decisive step toward the discovery of its infinity, speculative concreteness. Methodologically verified certification of this goal achievement becomes

\footnotetext{
${ }^{7}$ On the one hand, Marx perceptively characterizes The Phenomenology as "the true point of origin and the secret of the Hegelian philosophy" in his "Economic and Philosophic Manuscripts" (and, above all, on the material of Hegel's study of social life) [25, p. 136]. On the other hand, he is entirely at the mercy of the idea of the identity of self-consciousness and "pure", "abstract" thinking and the "encyclopedic system" reflecting its movement, not noticing the approach to the consideration of sociality in The Phenomenology, access to which was closed during the subsequent evolution of Hegel's views. Of course, the last remark should not be taken as a "reproach" to the great thinker, which would be completely unhistorical in relation to his scientific and philosophical researches.
} 
the basis for the scientific study of man and society, since the concreteness of the spirit is fully revealed exclusively in the system of social cohesion.

\section{Conclusion}

The idea of sociality construction, reflected in The Phenomenology of Spirit, arises in the context of Hegel's revision of the idea of the possibility of direct comprehension of truth in philosophical knowledge, being one of the elements of this fundamental change in the thinker's interpretation of the essence of the philosophical method. The imaginary immediacy of sociality appears as the "surface" of certain stages (formations) of the dialectically developing integrity of the spirit. Their common "place of birth" is the sphere of self-consciousness, in which, being the subject of the "doubling" movement as a means to reveal inner concreteness of the substance through the interaction, they contribute to the process of the sociality construction as the layer of objectivity, which provides the possibility to get to the speculative concreteness of the spirit, its performance as "absolute knowledge". Sociality as a subject of scientific knowledge (not an ordinary idea) is inaccessible for a "pre-philosophical" view of social life. It is a "reflected unity," which is revealed in terms of rational, scientific, and philosophical analysis. Therefore, it is worth highlighting the idea that sociality construction avoids the possibility to overcome the "evaluative approach" to social life in the humanities and social sciences, as well as the achievement of a certain "analog" of objective knowledge, which natural and mathematical sciences are proud of. ${ }^{8}$ Further research on the problem considered in the present article can be connected both to a comprehensive study of the development of sociality construction in The Phenomenology of Spirit and to the identification of the significance of the historical and philosophical prerequisites for the formation of the idea of cognition objectivity in the humanities and social sciences for modern discussions about their method and place in culture.

\section{References:}

1. Baklanova O.A., Baklanov I.S., Kolomak A.I., Pokhilko A.D. Sociality as a socialphilosophical problem. Life Science Journal. 2014. №11. P. 5-7.

2. Baklanova O.A. Sociality as a problem of social philosophy. The Philosophy of Law. 2013. №5. P. 62-65.

3. Bodamer Th. Hegels Deutung der Sprache: Interpretationen zu Hegels Äußerungen über die Sprache. Hamburg: Meiner, 1969. 304 S.

4. Dilthey W. Die Jugendgeschichte Hegels und andere Abhandlungen zur Geschichte des deutschen Idealismus. Gesammelte Schriften. Bd. 4. Stuttgart: B.G. Teubner, 1990. $583 \mathrm{~S}$.

5. Dove K.R. Die Epoche der Phänomenologie des Geistes . Hegel-Studien. Beiheft 11. Bonn: Bouvier Verlag, 1983. S. 605-621.

6. Dove K.R. Hegel's Phenomenological Method. The Review of Metaphysics. Volume 23, Issue 4 (1970). P. 615-641.

7. Foucault M. The Order of Things. An Archaeology of the Human Sciences. N.Y.: Vintage Books Edition, 1994. 387 p.

8. Gauvin J. Le «für uns» dans la Phénomélogie de l'Esprit. Archives de philosophie. XXXIII (1970). P. 829-854.

\footnotetext{
8 This is precisely the "analogue", since the subject is not excluded here from cognition process. Therefore, the phenomenological and hermeneutic components are considered as necessary elements of the methodology of the humanities and social sciences.
} 
9. Gupta J.A. Hegel on Logic, Determinacy, and Cognition. The Philosophical Forum. 2004. Vol. 35. Issue 1. P. 81-96. DOI: 10.1111/j.0031-806X.2004.00161.X

10. Haym R. Hegel und seine Zeit. Darmstadt: Wissenschaftliche Buchgesellschaft, 1962. $512 \mathrm{~S}$.

11. Hegel G.W.H. Philosophy of religion. Vol. 1. M.: Mysl', 1970. 532 p.

12. Hegel G.W.F. Gesammelte Werke. Bd. 1. Frühe Schriften. Theil I. Hrsg. v. F. Nicolin und G. Schüler. Hamburg: Felix Meiner, 1989. XVI, 656 S.

13. Hegel G.W.F. Gesammelte Werke. Bd. 2. Frühe Schriften. Theil II. Hrsg. v. W. Jaeschke. Hamburg: Felix Meiner, 2014. VIII, 714 S.

14. Hegel G.W.H. Phenomenology of Spirit. Translated by T. Pinkard. URL: https://www.academia.edu/16699140/Translation_of_Phenomenology_of_Spirit

(10.08.2019).

15. Hegel G.W.H. Raboty raznykh let [Works of different years]. Vol. 1. M.: Mysl', $1970.668 \mathrm{p}$.

16. Hyppolite J. Genesis and structure of Hegel's Phenomenology of Spirit. Evanston: Northwestern University Press, 1974. 609 p.

17. Kohl E. «Gestalt»: Untersuchungen $\mathrm{zu}$ einem Grundbegriff in Hegels «Phänomenologie des Geistes». München: H Utz Verlag, 2003. 346 S.

18. Kreines J. Hegel's Metaphysics: Changing the Debate. Philosophy Compass. 2006. Vol.1. Issue 5. P. 466-480. DOI: 10.1111/j.1747-9991.2006.00033.x.

19. Korotkikh V.I. "Phenomenology of the Spirit" and the problem of the structure of the system of philosophy in the works of Hegel. M.: INFRA-M, 2011. 381 p.

20. Korotkikh V.I. The Idea of the System of Philosophy in Hegel's Works. Indian Journal of Science and Technology. Vol. 8, (S10), IPL0800, December 2015. DOI: 10.17485/ijst/2015/v8is(10)/84849.

21. Korotkikh V.I. The structural principles of Hegel's the phenomenology of spirit narrative. Amazonia Investiga. Vol. 8. Num.18 / Enero-febrero 2019. P. 185-197.

22. Korotkikh V.I. The figure of the narrator as an element of a strategy in the interpretation of Hegel's «the phenomenology of spirit». Amazonia Investiga. Vol. 8. Num. 24 / Diciembre 2019. P. 71-81.

23. Labarriere P.-J. Structure et mouvement dialectique dans la Phénoménologie de l'Esprit de Hegel. P.: Aubier, 1968. 316 p.

24. Lumsden S. The Rise of the Non-Metaphysical Hegel .Philosophy Compass. 2008. Vol. 3. Issue 1. P. 51-65. DOI: 10.1111/j.1747-9991.2007.00115.x.

25. Marx K. Economic and Philosophic Manuscripts of 1844. Moscow: Progress Publishers, 1977. $226 \mathrm{p}$.

26. Marx W. Die Dialektik und die Rolle des Phänomenologen. Hegel-Jahrbuch, 1974. Köln: Pahl-Rugenstein Verlag, 1975. S. 381-387.

27. Marx W. Hegels Phänomenologie des Geistes. Die Bestimmung ihrer Idee in «Vorrede» und «Einleitung». Fr. am M.: Vittorio Klostermann, 1981. 236 S.

28. Nohl H. Hegels theologische Jugendschriften. Fr./M.: Minerva, 1966. 405 S.

29. Parry D.M. Hegel's Phenomenology of the «We». N.Y.: P. Lang, 1988. 216 p.

30. Plotnikov N. Georg Wilhelm Friedrich Hegel. Frühe Schriften II. Band 2 der Gesammelten Werke [Rezension] . Hegel-Studien. Bd. 49. 2016. S. 179-185.

31. Rosenkranz K. Georg Wilhelm Friedrich Hegels Leben. Darmstadt: Wissenschaftliche Buchgesellschaft, 1969. $566 \mathrm{~S}$.

32. Shmerlina I.A. Sociality and the problem of meaning: towards the development of an interdisciplinary concept. Epistemologiya i filosofiya nauki. 2009. Vol. XXI, №3. P. 137-151. 
33. Shmerlina I.A. Semiotic concept of sociality: problem statement. Sociologicheskij zhurnal. 2006. №3-4. P. 25-45.

34. Suhachev N.L. Concepts of language in European philosophy (Essays on G.W.F. Hegel, Ch.S. Peirce, M. Heidegger)]. Sankt-Petersburg: Nestor-Istoriya, 2007. 318 p. 35. Verene D.Ph. Hegel's Absolute: An Introduction to Reading the Phenomenology of Spirit. Albany: State University of New York Press, 2007. 131 p.

36. Verene D.Ph. Hegel's Recollection: A Study of Images in the Phenomenology of Spirit. Albany: State University of New York Press, 1985. 148 p.

37. Vernon J. Hegel's Philosophy Language. L.: Continuum, 2007. 161 p. 